\title{
Is Risk Based Capital Ratio a True Measure of the Soundness of Banks? Evidence From India
}

\author{
J. Navas ${ }^{1}$, P. Dhanavanthan ${ }^{1} \&$ D. Lazar ${ }^{2}$ \\ ${ }^{1}$ Department of Statistics, Ramanujan School of Mathematical Science, Pondicherry University, Pondicherry, India \\ ${ }^{2}$ Department of Commerce, School of Management Studies, Pondicherry University, Pondicherry, India \\ Correspondence: J. Navas, Research Scholar, Department of Statistics, Ramanujan School of Mathematical Science, \\ Pondicherry University, Pondicherry 605014, India. E-mail: navas_jk@yahoo.co.in
}

Received: August 13, 2020

Accepted: November 8, 2020

Online Published: January 11, 2021

doi:10.5430/ijfr.v12n3p92

URL: https://doi.org/10.5430/ijfr.v12n3p92

\begin{abstract}
The capital to risk-weighted assets ratio (CRAR) introduced by the Basel Committee on Banking Supervision (BCBS) of the Bank for International Settlement (BIS) is widely used as an important measure of the soundness of banks. However, international institutions, academics, and market analytics have increasingly questioned the reliability of the ratio which has been revised a number of times since its inception, to make it more robust. The main objective of the present study is to assess the adequacy of using CRAR as a measure of the soundness of banks. One of the most popular methods used for the analysis of the banks' financial soundness is CAMELS framework which uses six key dimensions: capital adequacy, asset quality, management quality, earning ability, liquidity, and sensitivity to market risk. Before the introduction of CRAR, the ratio of capital to the total assets was widely used as a measure of capital adequacy in the CAMELS framework. However, when risk-based CRAR was introduced, banking regulators and policymakers started using it in the CAMELS framework for representing capital adequacy. In this paper, we argue that CRAR, as a comprehensive forward-looking measure, encapsulates all the six dimensions of the financial soundness of banks, representing various facets of banking operations, which are covered in the CAMELS framework. We, therefore, develop a theoretical framework to establish the relationship between risk-based CRAR and the important ratios used under the CAMELS framework and then empirically investigate the relationship using a panel regression model using data of Indian banks for the period 2009-2018. The results indicate that CRAR has a significant and theoretically consistent relationship with all six dimensions of the CAMEL framework. The study, therefore, does not only confirm the appropriateness of using CRAR as a measure of the soundness of banks, but also opens up a debate on whether CRAR can be an alternative for the CAMELS framework.
\end{abstract}

Keywords: capital adequacy, financial soundness, camels model, banking regulation

\section{Introduction}

Banks play a crucial role in the development of a country. Banks through the intermediation process mobilize savings, lend to various segments of the economy, and promote economic growth. The sustainability and growth of the banking sector are, therefore, very important for the development of the financial sector as well as for economic growth. However, the very nature of the banking business has many inherent risks, such as credit risk, market risk, operational risk, liquidity risk, etc. If any of these risks materialize and the bank incurs unexpected losses, it can adversely influence the stability of its banking operations. It can even lead to bank failure, loss of confidence in the banking system, and affect the stability of the entire financial system and the stability of the economy. Banks, therefore, have to be financially sound to sustain themselves and grow.

One of the methods employed to mitigate such risks is maintaining adequate capital and reserves to absorb unexpected losses in order to protect the depositors' money, to ensure the stability of the bank's operations, and the entire financial system. An obvious question, then, is this: How much capital banks should maintain to ensure the confidence of the depositors, regulators, and other stakeholders? Until the introduction of capital to risk-weighted assets ratio (CRAR), there was no international standard to measure the adequacy of capital or minimum requirement for banks. Capital regulation has been designed to improve the safety and soundness of banks. Its theoretical foundations rest on the view that in the absence of minimum regulatory requirements, banks will hold insufficient capital to absorb losses (Lesle \& Avramova, 2012). Before CRAR, the regulators used to prescribe the leverage ratio, 
the ratio of capital to total assets, to be maintained by the banks. However, realizing that risk varied from bank to bank, the Basel Committee recommended that capital requirement should be proportional not only to the absolute value of the assets of banks but also to the level of risk arising out of each asset. Accordingly, CRAR was introduced, wherein the capital to be maintained by banks is proportional to their risk-weighted assets. A risk-weighted asset is the weighted sum of all assets with weights proportional to the risk level of each asset. This ratio has been widely used as an important measure of the soundness of banks. However, the reliability of the ratio is increasingly being questioned and numerous refinements were made to CRAR by the BASEL committee to make it more robust (BIS, 2017). The complexity involved in the calculation of CRAR and the number of components involved makes this measure difficult to understand. Particularly in the aftermath of the Great Financial Crisis, it was observed that many internationally active banks had built up excessive on- and off-balance sheet leverage, causing the crisis while maintaining a seemingly strong CRAR (BIS, 2017).

The Indian banks have also adopted the Basel capital adequacy norms since 1993 and during the last decade, almost all banks have maintained their CRAR above the regulatory requirement prescribed by the Reserve Bank of India. The very basic objective of implementing the Basel accords was to ensure that banks maintain minimum capital with respect to the risks faced by the banks. If the risk weights used for CRAR calculation is not sensitive to risks or if the quality of the capital maintained by banks is not sufficient or if there exists any regulatory arbitrage for capital requirement for certain exposures, a higher CRAR may give a false sense of soundness of the financial condition of the banks to the management and the regulators as well as depositors. As the banks have incurred a huge cost for implementing the mandatory Basel accords and for infusing additional capital to maintain the required minimum CRAR, the stakeholders expect the CRAR to capture all aspects of banking operation. It is even more significant in the Indian context because a large number of banks are owned by the government and infusion of additional capital to maintain the required CRAR comes from the government as taxpayers' money. It is, therefore, very important for policymakers to ensure that the CRAR so computed is a true measure of the soundness of banks.

This paper, therefore, aims to assess the adequacy of using CRAR as a measure of the soundness of banks. One of the most popular methods used to measure the banks' financial soundness is the CAMELS framework introduced by the Federal Financial Institution Examination Council (USA) in 1979 (Dang, 2011). CAMELS framework uses six key dimensions to assess the financial soundness of banks: capital adequacy, asset quality, management quality, earning ability, liquidity, and sensitivity to market risk. In this paper, we argue that CRAR takes into account various aspects of banking operations and develop a theoretical framework to establish the relationship between CRAR and the important ratios used under CAMELS framework and then empirically investigate the relationship using a panel regression model using data for Indian banks during the period 2009-2018. Before the introduction of CRAR, banking regulators and policymakers used the ratio of capital to the total assets for representing capital adequacy in the CAMELS framework. However, when risk-based CRAR was introduced, they started using the same in the CAMELS framework to represent capital adequacy. This paper further investigates whether this approach is appropriate as CRAR is also related to other dimensions of the CAMELS framework. The study, therefore, does not only help the regulators and other stakeholders of banks in examining the appropriateness of using CRAR as a measure of banks' financial soundness, but also open a debate on using CRAR itself as a comprehensive measure of the financial soundness of banks instead of the multi-parameter CAMELS framework. To the best of our knowledge, this paper is the first in assessing the linkages between CRAR and the CAMELS framework. In this process, the study also tests many hypotheses related to the CRAR such as the impact of leverage on CRAR, the impact of profitability on CRAR, risk sensitivity of CRAR to different types of risks, whether there is any regulatory arbitrage on certain types of exposures such as investments and off-balance sheet exposures.

The paper is divided into five sections. The next two sections consist of the literature survey related to capital adequacy of banks and theoretical linkage between CRAR and CAMELS framework. Section 4 covers the econometric model, hypotheses, and data sources. Section 5 presents the descriptive statistics, estimated model, and discusses the impact of dependent variables on CRAR. The last section summarizes the findings of the study with a few suggestions.

\section{Literature Survey}

The literature on capital adequacy ratios is very comprehensive. Many studies have used CRAR as a measure of the financial soundness of banks examining their performance, efficiency, assigning supervisory rating, etc. under the CAMELS framework. They include Girardone, Molyneux, and Gardener (2004) on the economics of banks; Estrella, Park, and Stavros (2000) on predicting banks' failure; Ramachandran (2012) on modifications in risk rating for banks in India; IMF and World Bank (2005), Roman and Saragu (2013), Dang (2011) and Rahman and Islam (2017) have used CRAR to represent capital adequacy in CAMELS framework while assessing the financial soundness of banks. 
Although there are many studies on the association of CRAR with other financial indicators, CRAR as a measure for the soundness of banks has not been explored exclusively. Pioneering studies on the relationship of CRAR with other financial ratios include Dahl and Shrieves (1990) and Peltzman (1970). Ediz, Michael, and Perraudin (1998) studied the capital ratio of Swiss banks. Joosen (2002) studied the CRAR of the banks of the Netherland and other European banks.Studies such as Kleff and Weber (2008) and Stolz and Wedow (2005) focused on identifying the determinants of CRAR in Germany. They found a significant relationship between risky assets and yearly variation in CRAR driven by the risk, a positive correlation between a bank's profitability and CRAR, a significant positive correlation between clients' deposits and CRAR, and a negative correlation between a bank's size and CRAR. Boucinha and Ribeiro (2008) studied the CRAR of Portuguese banks and found that in Portuguese larger banks hold less excess capital than small banks and banks with higher risk tend to hold higher capital reserves. Olalekan and Adeyinko (2013) studied the determinants of CRAR of Nigerian banks and found a significant positive relationship between capital adequacy and banks' profitability. Bateni, Vakiliford, and Asghari (2014) examined the impact of seven financial factors on CRAR in Iranian private banks during the period 2006-2012 and found that CRAR has a significant negative association with bank size, positive association with loans assets ratio (LAR), ROE, ROA and no significant association with deposits assets ratio and risk assets ratio. Masood and Ansari (2016) analysed the impact of the bank specific factors such as ROA, ROE, Loan to Asset ratio, Loan Loss Reserves, Non-Performing Loans, Deposit Asset Ratio, Equity Asset Ratio and Ownership concentration on CRAR of Pakistani banks. Majumder and $\mathrm{Li}$ (2018) investigated the impacts of bank capital requirements on the performance and risk of the Bangladeshi banking sector. They found that bank capital is positively related to bank performance and negatively related to risk. In the Indian context, only very few studies examined the determinants of CRAR. Nachane and Ghosh (2001) studied banks' behavior with respect to the CRAR of Indian banks by regressing changes in capital ratios with respect to net interest income, fee income, deposits, off-balance sheet exposure, total profit, etc. over risk-weighted exposure using quarterly data from 1997 to 1999. Mohanty and Mahakud (2018) examined the effect of the capital ratio on risk using variables such as NPA, loan loss reserve, equity to the total assets, and ROA. The paper reported that risk is positively affecting the CRAR. Das and Deb (2018) studied the association of capital adequacy and insolvency risk of the Indian Banks. The study reported that CRAR and the overall risk of the banks measured as a Z-Score of ROA and capital to the total assets are inversely related.

The studies on the association of CRAR with other financial indicators of the banks are not unanimous on the empirical evidence or the theoretical justification for the association or the direction of the relationship. Further, none of these studies attempted to examine CRAR in the CAMELS framework. As the effectiveness of the CRAR as a measure of the soundness of banks is increasingly questioned by stakeholders( Lesle and Avramova,2012) particularly after the 2008 global financial crisis, this study aims to reinstitute confidence in this measure.

\section{Theoretical Linkage Between CRAR and CAMELS Framework}

In this section, we argue that CRAR, as a comprehensive forward-looking measure, encapsulates all the six dimensions of the financial soundness of banks, representing various facets of banking operations, which are covered in the CAMELS framework.

According to Basel rules, banks are required to set aside minimum capital to cover three major risks: credit risk, market risk, and operational risk. However, banks are encouraged to assess the risks such as liquidity risk, interest rate risk, credit concentration risk, strategic risk, reputational risk, etc., which are not covered in Pillar 1 of Basel guidelines as a part of their internal capital adequacy assessment program (ICAAP), and maintain additional capital to cover them too.

CRAR is calculated as a ratio of the total capital to total risk-weighted assets, and all internationally active banks are required to maintain a CRAR above $8 \%$.

$$
C R A R=\frac{\text { Tier I Capital }+ \text { Tier II Capital }}{\text { RWA for Credit Risk }+R W A \text { for Market Risk }+R W A \text { for Operational Risk }}
$$

where the RWA for Credit Risk is calculated as risk-weighted exposure of a bank's credit risk exposure whereas the RWA for Market Risk and RWA for Operational Risk are calculated by converting the capital required for market and operational risks into the equivalent amount of risk-weighted assets by multiplying them by $12.5(1 / 8 \%)$.

The six key areas - capital adequacy, asset quality, management quality, earnings ability, liquidity, and sensitivity to market risks - of the potential strengths and vulnerabilities are considered as financial soundness indicators of the banking sector in the CAMELS framework(IMF \& World Bank, 2005). The literature review indicates that researchers have used different financial ratios to represent each of the above aspects. Below, we present the 
important ratios used under the CAMELS framework and their theoretical linkage with CRAR.

Capital adequacy: The basic purpose of CRAR itself is to ensure that banks have adequate capital to address the risk of insolvency. Capital adequacy and availability ultimately determine the robustness of financial institutions to withstand balance sheet shocks. Initially, in the CAMELS framework, the ratio of capital to the total assets was used to calculate the insolvency risk and other risks were calculated separately. The calculation in CRAR requires banks not only to maintain the minimum capital but also to ensure the quality of the capital, which is also required to be proportional to the risks addressed separately in the CAMELS framework through asset quality, liquidity, and sensitivity. Unlike the CAMELS framework, the Basel accord clearly defines the items that can be treated as capital for CRAR calculation; they are broadly grouped into two categories Tier- 1 capital and Tier- 2 capital. Tier- 1 capital is considered as going-concern capital since it can absorb losses without triggering bankruptcy and Tier-2 capital is considered as gone-concern capital because it will absorb losses only when the bank is liquidated. CRAR calculation also puts restrictions on the composition of capital to improve the quality of the capital. For example, Tier- 2 capital, which was admitted to $100 \%$ of Tier-1 capital under Basel II, was further restricted to a maximum of up to $2 \%$ of the RWA under Basel III. The share capital, reserve and surplus generally account for a major portion of the Tier-1 capital. As the soundness of banks with respect to various risks are captured separately in CAMELS framework, we argue that the non-risk based leverage ratio (LR), introduced in Basel III, defined as the ratio of Tier-1 capital to total adjusted exposure is more appropriate to gauge capital adequacy in CAMELS framework. Accordingly, we expect a positive relationship between CRAR and LR.

Asset Quality: Risks of solvency in financial institutions most often arise from impaired assets, which in turn can arise from a deterioration in the financial health and profitability of the borrowers. The ratio of non-performing loans (NPLs) to total gross assets and the ratio of provisions to NPLs are often used to measure asset quality in the CAMELS framework (Roman \& Şargu, 2013). In CRAR, the asset quality is captured through risk-weighted assets for credit risk used in the denominator of the ratio. While the CAMELS framework captures only the present status of the asset quality, CRAR does not only capture the present status of asset quality through higher risk weight assigned to NPAs, but also the likelihood of future NPLs through risk weights based on borrower ratings. Asset quality can also be impaired due to other factors such as risk arising out of large concentration of credits, country risk, etc. Basel guidelines require banks to maintain additional capital for such risks under the ICAAP program. Further, the exposure to off-balance sheet items such as guarantees, derivatives, etc., are generally not used in models based on CAMELS framework; however, the CRAR calculation explicitly considers such exposures for RWA calculation of credit risk. A few researchers (e.g., Rahman \& Islam, 2017) have used other ratios such as investments to assets ratio, loans to assets ratio, etc. also to represent the asset quality. However, we argue that decisions on asset composition depend more on perceptions of banks' management about risk and return. We, therefore, use them to assess the relationship between CRAR and management quality.

Management quality: Management quality is another indispensable constituent of the CAMELS framework. The ratios such as total advances to total deposits, business per employee, profit per employee, etc. are generally used to assess the management quality in the CAMELS framework. However, we argue that with the technology-driven banking environment, where banks spend huge amounts on technology, comparing profit with the number of employees no longer makes sense. Similarly, since banks use multiple sources for their funding requirements, we argue that instead of measuring management quality based on banks' efficiency to transform deposits to advances, it should be measured based on banks' efficiency to allocate the total fund into different asset types that optimizes the risk and reward. So, we use a set of variables that represent the asset distributions such as investment to total assets and contingent liabilities to total assets as measures of management quality.

Earning Quality: High earnings quality should reflect the firm's current operating performance and is a good indicator of future operating performance. Accounting data on bank margins, income, and expenses are widely used indicators of bank profitability. Common operating ratios used to assess bank profitability include return on assets (ROA), return on equity (ROE), operating profit over total assets (OPA) and net interest income over total assets (NIM; Roman \& Şargu, 2013). Profitability impacts the CRAR mainly through two channels. First, profitability improves banks' ability to increase the capital through reserves and surplus and through the new issue of shares. Second, since CRAR calculation requires banks to assign a risk weight to each asset and increase the capital proportionate to increased risk level, banks may charge higher fees and interest rates for risky assets to maintain the desired ROE. We have used the ratio of operating profit over total assets (OPT) to represent the earning aspects of the CAMELS framework.

Liquidity: Maintaining adequate liquidity is an important aspect of the soundness of banks. In a liquidity crisis, even solvent banks can be pushed into insolvency, because if they lose access to funding, they could be forced to sell 
assets at depressed prices to obtain liquidity. The commonly used measure of liquidity is liquid assets to total assets (liquid asset ratio), which indicates how much balance sheet shrinkage the sector could absorb before being forced to sell illiquid assets. Other measures are liquid assets to short-term liabilities, customer deposits to total (non-interbank) loans, government securities/total asset. CRAR does not directly capture liquidity risk, but as per the Basel guidelines, banks are required to maintain additional capital for liquidity risk under the ICAAP. In the wake of the 2008 global financial crisis, BCBS has also issued a new framework for liquidity management in banks in 2009 (BIS, 2019). The framework introduced two new measures: liquidity coverage ratio (LCR) and net stable funding ratio (NSFR) to measure and monitor the adequacy of liquidity. Considering the complexity involved and the lack of data in computing LCR and NSFR, we have used the commonly used measure, the ratio of liquid assets to total assets, to assess the relation between CRAR and banks' liquidity position.

Sensitivity to market risk: As banks take positions in financial instruments, they are exposed to the risk of losses arising from changes in market prices or to the market risk. Market risk includes risks pertaining to interest rate related instruments and equities in the trading book, foreign exchange risk, and commodities risk throughout the bank in both trading and banking books. However, the interest rate risk is considered a major market risk (Gonzalez, 1999). Total securities to total assets ratio and the GAP, the difference between risk-sensitive assets and risk-sensitive liabilities are frequently used to capture sensitivity to interest rate risk. A series of studies that used the CAMELS framework did not even consider sensitivity due to measurement difficulties based on the accounting and financial data (Roman \& Şargu, 2013; Rahman, 2017). CRAR calculation under the Basel guidelines explicitly captures the market risk through the component risk-weighted assets for market risk. It proposes two approaches to capture market risk: standardized approach (SA) or internal model-based (IMB) approach and it covers market risk associated with investments of the banks in all types of instruments, interest rate-related products, shares, foreign exchange and other derivative products such as options, forward rate agreements (FRAs), other forward contracts, bond futures, interest rates, cross-currency swaps and forward foreign exchange positions, etc. Under the standardized approach, the capital charges for market risk is calculated based on the general and specific risks associated with investment. For interest-sensitive investments, the market risk is calculated based on the change in the value of investment for a given change in yield, using the modified duration of the concerned investment. So, CRAR captures sensitivity in a more comprehensive manner than CAMELS framework. For an empirical analysis of the sensitivity of CRAR, we have used the GAP ratio. Figure 1 summarizes the theoretical linkage between CRAR and CAMELS framework.

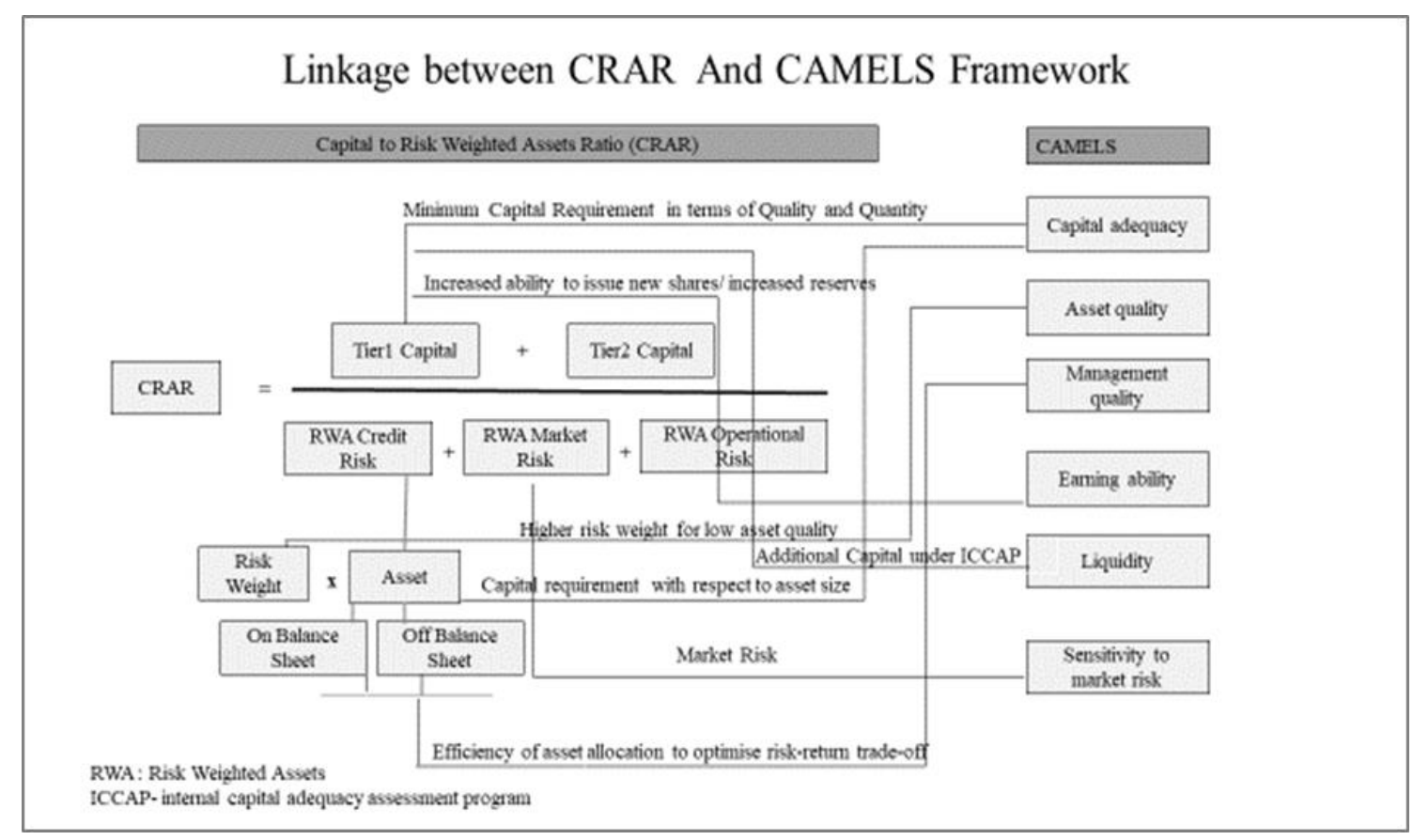

Figure 1. Linkage between CRAR and CAMELS framework

Source: Authors. 


\section{Methodology}

\subsection{Econometric Model and Hypotheses}

In view of our discussion in the previous section, the following panel regression equation is postulated for the CRAR of bank $\mathrm{i}$ in year $\mathrm{t}$ :

$$
\begin{array}{r}
\text { CRAR }_{i, \mathrm{t}}=\alpha+\beta_{1} \mathrm{LR}_{\mathrm{i}, \mathrm{t}}+\beta_{2} \mathrm{GNPA}_{\mathrm{i}, \mathrm{t}}+\beta_{3} \mathrm{IOTA}_{\mathrm{i}, \mathrm{t}}+\beta_{4} \mathrm{CLOTA}_{\mathrm{i}, \mathrm{t}}+\beta_{5} \mathrm{OPOA}_{\mathrm{i}, \mathrm{t}}+\beta_{6} \mathrm{LAOTA}_{\mathrm{i}, \mathrm{t}} \\
+\beta_{7} \mathrm{GAPTA}_{\mathrm{i}, \mathrm{t}}+\mu_{\mathrm{i}}+\epsilon_{\mathrm{i}, \mathrm{t}}
\end{array}
$$

where CRAR is the capital to risk-weighted assets ratio, LR is the ratio of Tier-1 capital to the total exposure, GNPA is the gross nonperforming assets over the performing assets, IOTA is investments over the total assets, CLOTA is the contingent liabilities (off-balance sheets exposure) over the total assets, OPOA is the operating profit over the total assets, LAOTA is the liquid assets over the total assets, and GAPTA is the sensitivity ratio measured as GAP over total assets. The constant $\mu_{\mathrm{i}}$ represents the bank specific effects that capture information on all the omitted variables that affect only cross-sectionally.

The ratio of Tier-1 capital to the total exposure (LR) is included in the model to study capital adequacy as well as the quality of capital. The ratio is calculated based on the methodology suggested in Basel III framework to calculate the LR. As the Tier-1 capital is considered going-concern capital that can absorb losses without triggering bankruptcy of the banks, banks with more Tier-1 capital are considered as financially sounder than others. Highly capitalized banks are likely to have lower bankruptcy costs, which in turn reduces funding costs, thus generating higher profits (Berger, 1995). Moreover, highly capitalized banks engage more in prudent lending and borrow less, which in turn reduces their costs and increases their profitability (Tan, 2016). Hence a positive correlation of LR with CRAR should be an indicator of the appropriateness of using CRAR as a measure of the soundness of banks.

Asset quality of banks is captured by including Gross Nonperforming Assets (GNPA) in the model. It captures the risk, particularly the credit risk, in the portfolio, a major component of the risk banks are exposed to. A higher level of nonperforming assets (NPAs) can results in an increase in the RWA due to higher risk weight assigned to nonperforming loans and hence the GNPA is expected to have a negative relation with CRAR.

The management quality of the banks is assessed by including both IOTA and CLOTA in the model. It also helps to understand the effect of skewness of the portfolio towards investment and off-balance sheet exposures, which are perceived to have regulatory arbitrage in the capital calculation. It is believed that credit conversion factors (CCFs) used to determine the amount of off-balance sheet exposure to be risk-weighted is less risk-sensitive (BIS, 2017). So, if the banks with a higher proportion of contingent liabilities have higher CRAR, it is an indication of regulatory arbitrage.

OPOA is included in the model to assess the impact earning quality of banks. In all earlier studies return on asset (ROA) was used to study the impact of profitability on CRAR. Since provision taken for NPAs is included in the ROA calculation, including ROA in the model together with NPA as another variable may lead to multicollinearity problems in estimating the model. Therefore, we use OPOA instead of ROA in our model. Banks with higher profitability can transfer more earnings to their reserve and surplus and thereby increase the capital. An increase in the capital, in turn, results in an improvement in the CRAR; hence, a positive coefficient should indicate the soundness of CRAR.

The ratio of liquid assets over the total asset (LAOTA) is included in the model to measure the association of liquidity risk and CRAR. The current or liquid assets include cash in hand, balance with the central bank, balance with banks in India, and money at call and short notice. As per the Basel II regulation, although banks are not required to calculate RWA exclusively for the liquidity risk, they are encouraged to maintain additional capital for liquidity risk. Hence, the banks with high liquidity risk (low LAOTA) are expected to have low CRAR, which means a positive coefficient of LAOTA indicates the soundness of CRAR.

To assess the sensitivity of CRAR for market risk, we include the gap ratio, GAPTA, in the model. Although market risk could be due to movement in the interest rate, equity price, exchange rate or commodity price, etc. the interest rate risk is considered as a major component of market risk in India. Financial institutions normally perform GAP analysis to assess the impact of interest rate movement on the earnings of different segments of their interest-sensitive assets and liabilities. GAP of a bank during a given period is the difference between the value of its earning assets and the liabilities that mature or reprice during that period. The gap ratio is the ratio of the cumulative gap position to the total assets of the bank. The value of this ratio indicates the direction of interest rate exposure and the scale of the exposure relative to the size of the bank. A positive gap ratio is good if the interest rate is expected to 
go up and vice versa. In other words, when the yield curve is upward (downward) sloping, a positive(negative ) GAP represents the sensitivity of the ratio to interest rate risk. So we use a normalized GAP ratio in our model which takes the value -GAP, when the yield curve is downward sloping and +GAP when it is upward sloping. As the ratio increases, the portfolios become more exposed to interest rate risk. A negative relation between CRAR and GAP ratio, therefore, indicates the sensitivity of CRAR to market risk.

\subsection{Data Sample}

We used time series data on income, expenditure, assets, liabilities, and CRAR of commercial banks published by the Reserve Bank of India for this study. This data is compiled from the annual financial statements of banks. Our sample covers a panel data set of 461 bank-years covering 47 banks for the period from 2009 to 2018 . This includes 23 private banks and 24 public sector banks. As of March 2018, the banks included in our sample accounted for 95.9 percent of the total assets of all scheduled commercial banks operating in India. Among the selected banks, 65 percent of the assets were with the public sector banks and the rest with private sector banks.

\section{Results and Discussion}

The descriptive statistics of the data used in our analysis is presented in Table 1.

Table 1. Descriptive statistics of the variables

\begin{tabular}{|c|c|c|c|c|c|}
\hline & Mean & Median & Maximum & Minimum & Std. Dev. \\
\hline CRAR & 13.39 & 13.00 & 37.00 & 8.00 & 2.80 \\
\hline LR & 5.86 & 5.00 & 31.00 & 1.00 & 2.44 \\
\hline GNPA & 4.64 & 3.00 & 32.00 & 0.00 & 5.02 \\
\hline IOTA & 28.03 & 27.00 & 62.00 & 16.00 & 5.69 \\
\hline CLOTA & 131.58 & 34.00 & 1929.00 & 4.00 & 288.83 \\
\hline OPOA & 2.05 & 2.00 & 6.00 & -1.00 & 0.89 \\
\hline LAOTA & 6.87 & 6.00 & 26.00 & 2.00 & 2.83 \\
\hline GAPTA & 15.67 & 13.00 & 54.00 & 0.00 & 11.52 \\
\hline
\end{tabular}

Source: Author.

Table 2 provides the correlation between the variables used in our analysis. A low correlation between dependent variables indicates that they do not interact with each other and hence do not pose any multicollinearity problems for the estimation of our econometric model. Further, the sign of the correlation of the dependent variables with CRAR is as expected in the previous section.

Table 2. Correlation between CRAR and independent variables

\begin{tabular}{lrrrrrrrr}
\hline & CRAR & OPOA & GNPA & LAOTA & GAPTA & T1COTC & CLOTA & INVOTA \\
\hline CRAR & 1.00 & & & & & & & \\
LR & 0.80 & 1.00 & & & & & & \\
GNPA & -0.33 & -0.15 & 1.00 & & & & & \\
IOTA & 0.41 & 0.24 & -0.03 & 1.00 & & & & \\
CLOTA & 0.22 & 0.07 & -0.03 & 0.33 & 1.00 & & & \\
OPOA & 0.56 & 0.52 & -0.28 & 0.11 & 0.46 & 1.00 & & \\
LAOTA & 0.21 & 0.13 & 0.10 & 0.15 & -0.02 & 0.00 & 1.00 & \\
GAPTA & -0.12 & 0.09 & 0.10 & 0.01 & -0.28 & -0.33 & 0.00 & 1.00 \\
\hline
\end{tabular}

Source: Author. 
The combined effect of these variables on CRAR and their statistical significance is analyzed by estimating the econometric model (2). The main problem with the econometric analysis of the model (2) is to decide whether individual (bank-level) effects are fixed or random. The Hausman test on the model (2) rejects random effect at 1 percent significance level, providing evidence in favor of fixed effect. Accordingly, a fixed effect panel regression model is estimated using Eviews 8.0.

Table 3. Results of the Panel Regression (2) with CRAR as dependent variable

\begin{tabular}{|c|c|c|c|c|c|}
\hline & $\begin{array}{l}\text { Independent } \\
\text { Variable }\end{array}$ & Coefficient & Std. Error & t-Statistic & Prob. \\
\hline Capital & LR & 0.6863 & 0.0482 & 14.2365 & 0.0000 \\
\hline Asset Quality & GNPA & -0.1144 & 0.0119 & -9.6004 & 0.0000 \\
\hline \multirow{2}{*}{$\begin{array}{l}\text { Management } \\
\text { Quality }\end{array}$} & IOTA & 0.0964 & 0.0166 & 5.79369 & 0.0000 \\
\hline & CLOTA & 0.0007 & 0.0008 & 0.8819 & 0.3783 \\
\hline Earnings & OPOA & 0.2490 & 0.1108 & 2.2479 & 0.0251 \\
\hline Liquidity & LAOTA & 0.1543 & 0.0224 & 6.8877 & 0.0000 \\
\hline \multirow{4}{*}{$\begin{array}{l}\text { Sensitivity } \\
\text { Market risk }\end{array}$} & GAPTA & -0.0162 & 0.0092 & -1.7564 & 0.0798 \\
\hline & Constant & 5.8167 & 0.6789 & 8.56741 & 0.0000 \\
\hline & Adjusted R-squared & 0.8567 & \multicolumn{2}{|c|}{ F-statistic } & 45.9368 \\
\hline & Durbin-Watson stat & 1.3112 & \multicolumn{2}{|c|}{ Prob (F-statistic) } & 0.0000 \\
\hline
\end{tabular}

Source: Author.

The results of the estimation of the model (2) reported in table 3 show that the non-risk based capital ratio (LR) has a positive and significant correlation with CRAR. This was expected because, in India, capital augmentation of banks was mostly through Tier -1 capital, which predominantly consists of equity capital as well as reserve and surpluses. Further, with the implementation of Basel III, there was a significant improvement in the quality and quaintly of Tier-1 capital, driven by the Basel III measures. At the same time, the risk level has not changed significantly over time resulting in a co-movement of CRAR and LR. So the significant positive correlation of LR with CRAR indicates the robustness of CRAR to capture the insolvency risk of banks.

As expected, GNPA has a significant negative impact on CRAR. This is because NPA attracts higher risk weights in the calculation of RWA. Further, NPA also brings down the profitability of the banks and thus its ability to augment the capital either internally through retained earnings or externally through issuing new shares. Therefore, a decrease in capital and increase in RWA results in a reduction in CRAR. The result shows that banks with higher credit risk exposure have lower CRAR, indicating CRAR's ability to capture the asset quality of banks' credit portfolios.

Both the ratio of investment over total assets (INVOTA) and contingent liabilities to total assets (CLOTA) are found to have a positive association with CRAR, indicating that management decisions to diversify the portfolio to low-risk assets such as investments and contingent liabilities reflected in a higher CRAR. The investment portfolio of a bank in India mostly consists of government securities, which are less risky compared to loans and advances. Under section 24 of the Banking Regulation Act, 1949, banks in India are required to maintain a certain level of minimum liquid assets (statutory liquidity ratio, SLR) in the form of investments in government securities as a percentage of demand and time liabilities (DTLs) of the banks. Since the investment in SLR securities attracts zero risk weight for credit risks and capital is required only for market risk, the banks may tilt its asset portfolio, particularly when they have surplus liquidity, more towards such investments. From the management perspective, the positive association of IOTA with CRAR indicates the efficiency of portfolio allocation with respect to risk-return tradeoff. Although CLOTA is positively correlated with CRAR, it is not statistically significant, which rejects the hypothesis that banks having higher exposure to such contingent liabilities benefit from regulatory arbitrage. The contingent liabilities consist of different products and each of which gets differential treatments for RWA calculation in CRAR through varying credit conversion factors. The composition of contingent liabilities also vary significantly from bank to bank. 
Hence the interpretation of the coefficient of CLOTA becomes even more difficult. Nevertheless, the coefficients of these variables show that management quality certainly reflects in CRAR.

OPOA has a significant positive correlation with CRAR confirming the findings of the earlier studies that profitability indeed has a positive association with CRAR. In India during the study period, banks augmented their capital, the numerator of CRAR, significantly through the accumulation of reserve and surplus from their earnings. The CAGR of the statutory reserve (23 percent) further confirm our results. This reserve growth was driven by the statutory regulation that required banks to transfer not less than 25 percent of the net profit (before appropriation) to the reserve fund as statutory reserves. So, from the profitability perspective, CRAR is a good measure of the soundness of banks.

The liquidity risk indicator, LAOTA has a significant positive association with CRAR, indicating that banks with low liquidity risk maintain a high CRAR. This further confirms that banks assess the liquidity risk (which is not covered for RWA calculation under Basel rules) as a part of the required the ICAAP and maintain additional capital for it. So, an increase in capital without a proportional increase in the RWA could be a reason for higher CRAR. In any case, the result indicates that CRAR captures the liquidity aspects of banks' operations.

The negative coefficient of GAPTA indicates that banks with a higher asset-liability gap have a lower CRAR, indicating the sensitivity of CRAR to the interest rate risk exposure. This coefficient is statistically significant too.

Overall, the study shows that the CRAR captures the soundness of the banks. However, more explorative studies using granular risk data are required to explain in detail the association between CRAR and the indicators of financial soundness. Such data is publicly not available. Further, if the CRAR is calculated by including RWA components for risks not covered in Pillar 1 of Basel accord such as liquidity risk, concentration risk, etc., it will become a more appropriate measure of the soundness of banks. Presently some banks maintain additional capital for such risks under ICAAP without considering the corresponding RWA. As ICAAP is not a standard process across banks, the present CRAR may not be comparable across banks.

\section{Conclusion}

In this study, we examined the appropriateness of using CRAR as a measure of the financial soundness of banks by theoretically and empirically investigating the relationship between this risk based capital ratio and a set of financial ratios, which are commonly used under the CAMELS framework to assess the soundness of banks. The results, as expected, show that CRAR of Indian banks has a significant positive association with the financial ratios that represent capital adequacy, profitability, and management quality of banks and a negative association with risk variables that represent asset quality, liquidity, and sensitivity to the market. Thus CRAR captures three key risks in banking operation namely credit risk, liquidity risk, and market risk. As the CRAR has a significant and theoretically consistent relationship with all the six key dimensions of the CAMELS framework, it can be concluded that CRAR is a good measure of the soundness of banks in India.

There are many reasons for such consistency in the relationship between CRAR and CAMELS model. Most importantly, the CRAR, as a comprehensive forward-looking measure, encapsulates capital as well as risks. As the Basel norms require banks to set aside minimum capital to cover all the major risks faced by the banks, the CRAR explicitly accounts for credit, market, and operational risks. Further, banks are also required to maintain a higher proportion of their capital in the form of Tier1 instruments such as equity, reserves, and surplus. As a result, banks with lower leverage, higher profitability, and efficient management can increase their capital ratio through an increase in capital. This is particularly true for Indian banks, as they augmented their capital mostly through Tier -1 instruments during the study period. During 2009-2013, when the banks were more profitable, they increased their capital mainly through reserves and retained earnings, whereas during 2014-2018, when many banks, particularly public sector banks, were on the loss they relied more on equity capital to increase their capital. On the other hand, the denominator of the capital ratio, the risk-weighted assets, captures all the major risks faced by the banks. The negative correlation of CRAR with NPA and GAP ratio reveals that banks with low credit risk and market risk maintain a higher capital ratio, which demonstrates CRAR's ability to capture the earning quality and sensitivity aspects of the CAMELS framework. Banks' ability to maintain a higher CRAR also depends on the quality of their management. A risk-conscious management may optimize the risk and return in the portfolio through efficient allocation of assets into different asset classes. Hence, instead of measuring the management quality through traditional approaches which are based on banks' efficiency to transform deposits to advances, we measured the management quality using the ratio of contingent liabilities to total assets and investments to the total assets. Both the ratios are positively correlated with CRAR indicating that management quality indeed has an impact on CRAR. Since the coefficient of the ratio of contingent liabilities to total assets is not statistically significant, the study rejects 
the hypothesis that banks increase their CRAR through leveraging regulatory arbitrage by having higher exposure to contingent liabilities.

The study, therefore, does not only confirm the appropriateness of using CRAR as a measure of the soundness of banks but also opens up a debate on whether CRAR itself can be a substitute for the CAMELS framework. Since CRAR has a significant correlation with all the six dimensions of the CAMELS framework, we recommend the use of a non-risk based capital ratio in the CAMELS framework to represent insolvency risk and CRAR as an independent measure to assess the overall soundness of banks. One of the major drawbacks of the CRAR is that the risk-weighted assets used in the denominator of the ratio does not capture the liquidity risk in the banks' portfolio. Despite that, the study reveals that CRAR has a negative relation with liquidity risk measured in terms of the ratio of liquid assets over total assets indicating that banks with higher liquidity risk maintain lower CRAR. This is because, as per Basel norms, banks are required to assess the liquidity risk separately as a part of banks' ICAAP and maintain additional capital for it. Therefore, an increase in capital without a proportional increase in the RWA could be a reason for the higher CRAR. Future studies on CRAR may address this issue by recalculating CRAR to exclude the additional capital taken for liquidity risk from the numerator of the CRAR or by including a RWA component in the denominator to account for the additional capital allocated for liquidity risk under the ICAAP. As the relationship of CRAR with the various indicators of financial soundness may be influenced by the economic environment in which the banks are operating and banks' ownership structure, the study could be further extended to examine whether the relationship between CRAR and the CAMELS framework holds good for different bank groups and for different economic scenarios.

\section{References}

Bank for International Settlement (BIS). (2009). Basel III: International framework for liquidity risk measurement, standards and monitoring. Retrieved from https://www.bis.org/publ/bcbs 188.htm

Bank for International Settlement (BIS). (2017). Basel III: Finalising post-crisis reforms. Retrieved from https://www.bis.org/bcbs/publ/d424.htm

Bateni, L., Vakiliford, H., \& Asghari, F. (2014). The influential factors on capital adequacy ratio in Iranian banks. International Journal of Economics and Finance, 6(11), 108-116.

Berger, A. N. (1995). The Profit-Structure Relationship in Banking-Tests of Market-Power and Efficient-Structure Hypotheses. Journal of Money Credit and Banking, 27, 404-431. https://doi.org/10.2307/2077876

Boucinha, M., \& Ribeiro, N. (2008). The determinants of Portuguese banks' capital buffers, Working Paper 1/2008. The Bank of Portugal.

Dahl, D., \& Shrieves, R. F. (1990). The impact of regulation on bank equity infusion. Journal of Banking and Finance, 14(6), 1209-28

Dang, U. (2011). The CAMEL rating system in banking supervision: A case study (Dissertation). Arcada University of Applied Science, International Business. Retrieved from http://www.studymode.com/essays/Camel-Rating-In-Banking-1737636.html

Das, N. M., \& Deb, J. (2018). A Statistical Re-assessment of Capital Adequacy and Insolvency Risk in Commercial Banks of India. In Mishra A., Arunachalam V., \& Patnaik, D. (Eds.), Current Issues in the Economy and Finance of India. ICEF 2018 2018. Springer Proceedings in Business and Economics. Springer, Cham. https://doi.org/10.1007/978-3-319-99555-7_7

Ediz, T., Michael, I., \& Perraudin, W. (1998). The impact of capital requirements on UK banks behaviour. Economic Policy Review, 4(3), 15-22.

Estrella. A., Park S., \& Peristiani, S. (2000). Capital ratios as predictors of bank failure. Economic Policy Review, 6(2), 33-52

Girardone, C., Molyneux, P., \& Gardener, E. P. M. (2004). Analysing the determinants of bank efficiency: The case of Italian banks. Applied Economics, 36(3), 215-227.

Gonzalez, H. B. (1999). Determinant of ex-ante banking system distress: A macro-micro economic empirical exploration of some recent episodes, Working Paper no. 99/33, 1999. International Monetary Fund.

IMF, \& World Bank. (2005). financial sector assessment: A handbook. Retrieved from https://www.worldbank.org

Joosen, B. P. M. (2002). Solvency and capital adequacy regulations for banks in the Netherlands. International Financial Law Review, 21(4), 17-20. 
Kleff, V., \& Weber, M. (2008). How do banks determine capital? Evidence from Germany. German Economic Review, 9(3), 354-372.

Lesle, V., \& Avramova, S. (2012). Revisiting risk-weighted assets, IMF Working Paper 1, 2/90. International Monetary Fund.

Majumder, M. T. H., \& Li, X.(2018). Bank risk and performance in an emerging market setting: the case of Bangladesh. Journal of Economics, Finance and Administrative Science, 23(46). Retrieved from https://www.emerald.com/insight/content/doi/10.1108/JEFAS-07-2017-0084/full/html

Masood, U., \& Ansari, S. (2016). Determinants of capital adequacy ratio a perspective from Pakistani banking sector. International Journal of Economics, Commerce and Management, 4(7). Retrieved from http://ijecm.co.uk/wp-content/uploads/2016/07/4716.pdf

Mohanty, S., \& Mahakud, J. (2018). Commercial bank capital and risk in India: Does financial crisis matter?. Cogent Economics \& Finance, 6(1). https://doi.org/10.1080/23322039.2018.1520424

Nachane, D. M., \& Ghosh, S. (2001). Risk-based standards, portfolio risk and bank capital: An econometric study. Economic and Political Weekly, 36(10), 871-876.

Olalekan, A., \& Adeyinka, S. (2013). Capital adequacy and banks profitability: An empirical evidence from Nigeria. American International Journal of Contemporary Research, 3(10), 87-93.

Peltzman, S. (1970). Capital investment in commercial banking and its relationship to portfolio regulation. Journal of Political Economy, 78, 1-26.

Rahman, Md. Z., \& Islam, Md. S. (2017). Use of CAMEL rating framework: A comparative performance evaluation of selected bangladeshi private commercial banks. International Journal of Economics and Finance, 10(1), $120-128$.

Ramachandran, R. (2012). Capital adequacy requirements and the behaviour of commercial banks: An analysis. GRA-Global Research Analysis, 1(5), 16-18.

Roman, A., \& Şargu, A. C. (2013). Analysing the financial soundness of the commercial banks in Romania: An approach based on the CAMELS framework. Procedia Economics and Finance, 6, 703-712. https://doi.org/10.1016/S2212-5671(13)00192-5

Stolz, S., \& Wedow, M. (2005). Banks' regulatory capital buffer and the business cycle: Evidence for German savings and cooperative banks, Discussion Paper Series 2: Banking and Financial Studies. Deutsche Bundes Bank Research Center.

Tan, Y. (2016). The impact of risk and competition on bank profitability in China. International Financial Markets, Institutions, and Money, 40, 85-110.

\section{Copyrights}

Copyright for this article is retained by the author(s), with first publication rights granted to the journal.

This is an open-access article distributed under the terms and conditions of the Creative Commons Attribution license (http://creativecommons.org/licenses/by/4.0/). 